\title{
Subjective health complaints in patients with lumbar radicular pain and disc herniation are associated with a sex - OPRM1 A118G polymorphism interaction: a prospective 1-year observational study
}

\author{
Eivind Hasvik ${ }^{1,2^{*}}$, Elina lordanova Schistad ${ }^{3}$, Lars Grøvle ${ }^{4}$, Anne Julsrud Haugen ${ }^{4}$, Cecilie Røe ${ }^{3}$ \\ and Johannes Gjerstad ${ }^{1,3,5}$
}

\begin{abstract}
Background: Earlier observations show that development of persistent pain may be associated with the genetic variability in the gene encoding for the $\mu$-opioid receptor 1, the OPRM1 A118G (rs1799971). The aim of this study was to investigate the association between OPRM1 genotype and subjective health complaints in patients with radicular pain and disc herniation.

Methods: A prospective, 1-year observational study was conducted at a hospital back clinic, including 118 Caucasian patients with lumbar radicular pain and MRI confirmed disc herniation. Single nucleotide polymorphism genotyping regarding the OPRM1 A118G was performed. The data of individuals with AA versus AG or GG were analysed separately by linear mixed models. The Subjective Health Complaints Inventory (0-81) including 27 common complaints experienced the previous month on a scale from not at all (0) to severe (3) was used as outcome. Pain, prior duration of leg pain, age, smoking status, and lumbar disc surgery were considered as covariates.

Results: In total 23 of 118 patients were carriers of the OPRM1 G-allele. All patients except female carriers of the $\mathrm{G}$-allele reported a decrease in pain from baseline to 1 year. Female carriers of the G-allele reported significantly higher subjective health complaints score during the study time span than male carriers of the G-allele when controlling for pain and pain duration.
\end{abstract}

Conclusion: The present data indicate that, when controlling for pain intensity and duration, subjective health complaints are associated with a sex - OPRM1 A118G polymorphism interaction in patients with radicular pain.

Keywords: $\mu$-opioid receptor 1, Sex, Subjective health complaints, Sciatica, Radiculopathy, OPRM1 A118G, rs1799971

\section{Background}

Patients with non-specific low back pain or lumbar radicular pain often report additional subjective health complaints [1-4]. In the literature such health complaints have also been referred to as multiple physical symptoms, functional somatic syndrome, medically unexplained symptoms or somatisation [5-8], and include report of headaches,

\footnotetext{
* Correspondence: eivhas@so-hf.no

1 National Institute of Occupational Health, Oslo, Norway

${ }^{2}$ Department of Physiotherapy, Østfold Hospital Trust, Fredrikstad, Norway

Full list of author information is available at the end of the article
}

pain, dyspnoea, gastrointestinal discomfort, anxiety and sadness [9]. In patients with lumbar radicular pain, previous work has shown that subjective health complaints may be associated with the severity of pain-related disability [2] and unfavourable outcome at 1 and 2 years follow-up [10].

The single nucleotide polymorphism (SNP) in the human gene coding for the $\mu$-opioid receptor 1 , the OPRM1 A118G (rs1799971), may affect nociceptive signalling. For example, carriers of the G-allele seem to have less pronounced effects of opioids [11-15], increased pressure pain thresholds [16] and reduced cortical responses to nociceptive olfactory $\mathrm{CO}_{2}$ 
stimulation, indicating decreased nociceptive activation [17]. However, the G-allele has been associated with higher pain ratings and amount of self-administered intravenous morphine in women after caesarean section $[18,19]$. Moreover, female carriers of the G-allele suffering from lumbar radicular pain and disc herniation reported significantly higher pain levels than males with the same genotype [20].

Of relevance to comorbid symptoms, the OPRM1 polymorphism has been associated with other physiological processes such as immune and inflammatory function [21,22], stress response [23,24], substance abuse [25], social attachment [26], social sensitivity to rejection [27], and reward mechanisms [28,29]. However, there is a scarcity of comparable genetic work done on the report of subjective health complaints. Hence, the aim of the present study was to investigate how this genetic variant affects such comorbid symptoms in patients with lumbar disc herniation and radicular pain. Previous data have demonstrated sex differences between male and female G-allele carriers regarding pain [20]. Our hypothesis was therefore that the effect of the OPRM1 G-allele could be different in men and women regarding the report of subjective health complaints.

\section{Methods}

\section{Patients, setting and procedures}

This study was part of a prospective, 1 year observational study on patients with suspected lumbar radicular pain and disc herniation who were referred to a back clinic at Oslo University Hospital, Ullevål (OUS), Norway, during 2007 to 2009. Patients were invited to participate by the clinic staff. Inclusion criteria were age 18-60 years, lumbar radicular leg pain with a corresponding lumbar disc herniation at the relevant side and level confirmed by magnetic resonance imaging, and positive straight leg raise test (defined as radiating pain below the knee, within $60^{\circ}$ elevation). Exclusion criteria were lumbar spinal stenosis, previous disc surgery at the same level, lumbar spine fusion at any level, generalised musculoskeletal pain, inflammatory rheumatic disease, diabetic polyneuropathy, cardiovascular disease, cancer, psychiatric disease, neurological disease, alcohol or drug abuse, completion of another surgery within 1 month, pregnancy, nondetectable genotype, non-European-Caucasian ethnicity or poor Norwegian language. Patients received a standard clinical examination and answered a comprehensive questionnaire at baseline and at 1 year. Blood samples were taken at inclusion.

Treatment followed practice as usual, without any preallocation or randomisation. The conservative management options comprised a brief cognitive intervention, activity guidance during the acute phase, and physiotherapy. The choice of conservative and/or surgical treatment was made at the discretion of each physician/surgeon. All participants received written information and signed an informed consent form. The study was approved by the Norwegian Regional Committee for Medical Research Ethics and the Norwegian Social Science Data Services.

\section{Measurements}

The number and severity of health complaints was measured by the Subjective Health Complaints Inventory (SHC) [9]. This questionnaire consists of 29 common somatic and psychological complaints, such as pain (6 items), headache, dyspnoea, gastrointestinal discomfort, anxiety and sadness (see Additional file 1 for full overview of questionnaire items). Participants grade the intensity of each complaint experienced during the previous month on a $0-3$ scale with the categories; not at all, a little, some, and severe. The SHC score is calculated by summation of item scores. The items leg pain during physical activity and low back pain are closely related to the patient's present pain complaint and consequently excluded in all analyses, making the total possible score 81. Data on SHC prevalence in the Norwegian general population [30] as well as comparisons with clinical samples have been published [2,4,31]. Pain severity was assessed by a 10-point numeric scale with endpoints no pain and worst possible pain, indicating pain in activity during the last week, as used previously [20]. Patients also reported duration of their leg pain prior to baseline. At inclusion the socio-demographic variables age, sex and smoking status were recorded.

\section{Genotyping}

Genotyping was performed after finished patient sampling. Genomic DNA was extracted from whole blood cells using FlexiGene DNA isolation kit (Qiagen), and single nucleotide polymorphism (SNP) genotyping was performed using predesigned TaqMan SNP genotyping assays (Applied Biosystems). Approximately 10 ng of genomic DNA was amplified in $5 \mu \mathrm{l}$ reaction mixture using a 384-well plate containing 1x TaqMan genotyping master mix (Applied Biosystems) and 1x assay mix. The latter contained the respective primers and probes. Probes were labelled with the TaqMan reporter dyes $\mathrm{Fam}^{\mathrm{Tm}}$ and $\mathrm{Vic}^{\oplus}$ to distinguish between the OPRM1 alleles, A or G. After initial denaturation and enzyme activation at $95^{\circ} \mathrm{C}$ for $10 \mathrm{~min}$, the reaction mixture was subjected to 60 cycles of $95^{\circ} \mathrm{C}$ for 15 seconds and $60^{\circ} \mathrm{C}$ for $1 \mathrm{~min}$. The reactions were performed on an ABI $7900 \mathrm{HT}$ sequence detection system. Negative controls containing water instead of DNA were included in every run. Genotypes were determined using the SDS 2.2 software (Applied Biosystems). Approximately $10 \%$ of the samples were re-genotyped, and the concordance rate was $100 \%$. 


\section{Analyses and statistics}

Genotypes were dichotomised into AA carriers (participants with homozygous A-alleles) or *G carriers (participants with heterozygous A/G-alleles or homozygous G-alleles) because only one patient was homozygous GG. Analyses were performed separately for female * $G$ versus male "G carriers, female AA versus female " $G$ carriers, male AA versus male * $G$ carriers, as well as female AA versus male AA carriers, using a linear mixed effects model approach. The outcome variable was SHC during the study time span. Both baseline and 1-year scores were included in the model. This was done to examine change over time by testing interactions between $\mathrm{SHC}$ and time. Pain, as measured at baseline and 1 year, duration of leg pain prior to inclusion, age, smoking status, and lumbar disc surgery during the follow-up were tested in univariate analyses. Multivariate analyses were built by including variables from the univariate analyses with $\mathrm{p}<0.1$. The baseline model consisted of the fixed factors shown in Table 1. Subsequent models tested random intercept, and random slope for pain intensity. The decision to test for random effects of pain was based on previous work showing genotype differences in pain intensity over time [20]. Subjectspecific random factors and covariance structure was based on a best fit approach, assessed by the small-sample version of Akaike's information criteria (AICc) [32]. The final model random factors included random intercept, and random slope for pain intensity. Scaled identity covariance structure for the random factors was used. Estimation was done by maximum likelihood. No centring or imputation was performed. Analyses were assessed for adherence to linear mixed effect model assumptions. The four comparisons were corrected with the Bonferroni method. A p value $<0.0125(0.05 / 4)$ was chosen as the significance level. Analyses were done using SPSS version 21.0 (IBM Corp., Armonk, NY).

\section{Results}

In total, 118 patients were included in the study of whom 112 (95\%) completed the 1-year follow-up. 23 patients were carriers of the OPRM1 G-allele, corresponding to a G-allele frequency of $10.2 \%$ in total (14\% among males, $7.3 \%$ among females). One woman was homozygous GG. Patient characteristics according to sex and genotype are presented in Table 2. All patients except the female *G-carriers reported a decrease in pain from baseline to 1 year. Figure 1 illustrates the SHC and pain scores at baseline and 1 year according to sex and genotype.

The results from the final linear mixed model, including pain intensity and duration, showed that female * $G$ carriers had significantly higher SHC score than male * $\mathrm{G}$ carriers, $F(1,44)=7.73, \mathrm{p}=0.008$. This effect of sex had a clear influence on SHC $(b=6.59,95 \%$ CI 1.2, 11.37), whereas the effect of pain $(b=0.92,95 \%$ CI $0.12,1.72$,
Table 1 Parameter estimates for predictors in the final linear mixed-effects regression model, with SHC during the study time $\operatorname{span}^{\dagger}$ as outcome $(n=23)$

\begin{tabular}{lcccc}
\hline & $\boldsymbol{b}$ & $\mathbf{S E}$ & $\mathbf{9 5 \%} \mathbf{C l}$ & $\mathbf{p}$ \\
\hline Estimates of fixed effects & & & & \\
Female $^{*} \mathrm{G}$ carrier (male $\left.{ }^{*} \mathrm{G}\right)$ & 6.59 & 2.37 & $1.2,11.37$ & 0.008 \\
Pain score $(0-10)^{\dagger}$ & 0.92 & 0.39 & $0.12,1.72$ & 0.025 \\
Pain duration (weeks) & 0.14 & 0.05 & $0.04,0.25$ & 0.010 \\
Time 1 year (baseline) & 1.91 & 1.13 & $-0.42,4.24$ & 0.103
\end{tabular}

Estimates of covariance parameters

Residual

$9.19 \quad 3.04 \quad 4.80,17.59 \quad 0.003$

Random effects

$\begin{array}{llll}1.75 & 0.65 & 0.85,3.63 & 0.007\end{array}$

Reference category or scale in brackets. +Both baseline and 1-year scores were included in the analysis.

$\mathrm{p}=0.025)$ and prior pain duration $(b=0.14,95 \%$ CI 0.04 , $0.025, \mathrm{p}=0.01$ ) was less pronounced. The subject-specific random factors had a significant effect in the final model $(b=1.75,95 \%$ CI $0.85,3.63, \mathrm{p}=0.007)$. When including SHC x time interaction the overall model fit was significantly reduced and this interaction was therefore not included in the final model. The final model and estimates of covariance parameters is presented in Table 1 .

The SHC score did not differ significantly between female AA and ${ }^{*} \mathrm{G}$ carriers, $\mathrm{F}(1,63)=1.63, \mathrm{p}=0.206$, between male AA and ${ }^{*} \mathrm{G}$ carriers, $\mathrm{F}(1,48)=2.48, \mathrm{p}=0.122$ or between female and male AA carriers, $F(1,88)=0.63$, $\mathrm{p}=0.43$.

\section{Discussion}

The present study shows that multiple subjective health complaints (SHC) are associated with the OPRM1 polymorphism. During the study time span female *G carriers reported significantly higher SHC scores than male

Table 2 Patient characteristics according to sex and genotype

\begin{tabular}{llllll}
\hline & \multicolumn{2}{l}{ OPRM1 AA genotype } & & \multicolumn{2}{l}{ OPRM1 *G genotype } \\
\cline { 2 - 3 } \cline { 5 - 6 } Nen & 36 & Women & & Men & Women \\
\hline Age & $42.9(10.3)$ & $39.6(9.5)$ & & $42.4(10.8)$ & $43.2(8.9)$ \\
SHC baseline & $14.67(9.63)$ & $13.29(8.55)$ & & $10.10(9.38)$ & $16.22(8.67)$ \\
SHC 1 year & $13.61(12.50)$ & $12.73(10.02)$ & $6.97(6.01)$ & $18.88(12.23)$ \\
Pain baseline & $6.07(2.68)$ & $5.66(2.66)$ & $5.68(3.14)$ & $5.17(2.50)$ \\
Pain 1 year & $3.84(3.12)$ & $3.12(2.90)$ & & $1.53(2.65)$ & $5.41(2.32)$ \\
Duration (weeks) & $22.6(18.9)$ & $33.3(30.9)$ & & $17.5(14.5)$ & $40.7(37.8)$ \\
Smoker & $50 \%$ & $27 \%$ & $36 \%$ & $44 \%$ \\
Surgery & $44 \%$ & $37 \%$ & $36 \%$ & $33 \%$ \\
\hline
\end{tabular}

Values presented as means with standard deviation (SD). 

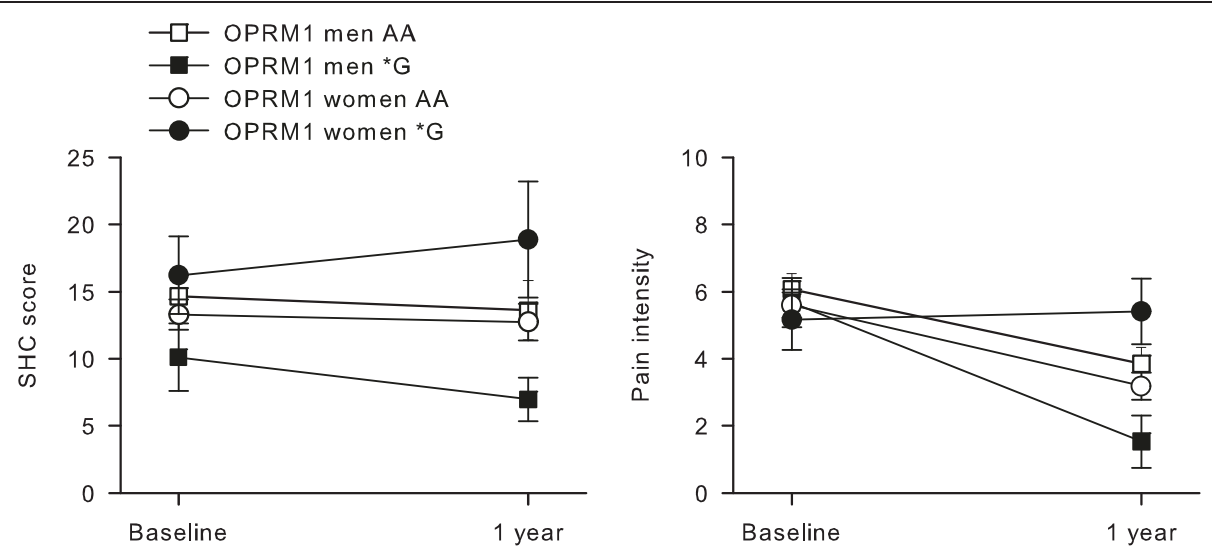

Figure 1 Subjective health complaints and pain scores (mean values \pm SEM) according to sex and genotype.

*G carriers. This was true also when controlling for pain intensity and prior duration of pain. Hence, the present data demonstrate that SHC may be a trait that in itself is linked to the OPRM1 genotype. Moreover, our results show that SHC in patients with lumbar radicular pain and disc herniation are associated with a specific sex OPRM1 polymorphism interaction. Previous data demonstrate an increase in $\mathrm{SHC}$ in patients with longer duration of radicular pain, indicating $\mathrm{SHC}$ to be secondary to pain and disability [2]. Our analyses however, suggest that the increased SHC might be more than just a phenomenon secondary to pain. No difference was found between female AA and *G carriers, male AA and ${ }^{*} \mathrm{G}$ carriers or female and male carriers of the AA genotype.

The sex - OPRM1 polymorphism interaction observed in the present study clearly support earlier findings. For example, it has been reported that $\mu$-opioid receptor binding potential may be higher with increasing age and in women [33]. Moreover, in one human experimental study, region-specific differences in OPRM1 levels between individuals with AA and G alleles have been demonstrated [34]. Additionally, the OPRM1 genotype may influence stress responses, immune and pro-inflammatory responses [21,35-37], and reactivity to social rejection [27]. Also, acute and chronic stress has been suggested to affect available $\mu$-opioid receptor pools in GABAergic interneurons differentially in female and male rats [38]. Exactly how this happens is not fully understood.

It is, however, now well established that the OPRM1 polymorphism leads to a substitution of the amino acid asparagine $(\mathrm{N})$ to aspartic acid (D) at position 40 of the extracellular receptor region. This affects the glycosylation site of the receptor, which is important for cellular processes such as receptor folding, sorting, expression and ligand binding [39]. The level and type of glycosylation are different between female and male mice [40-42], which may explain the sex-differences [43]. Hence, we think the OPRM1 polymorphism in a sex-specific manner also may affect supraspinal neuronal signaling in humans.

The SHC Inventory captures similar symptoms as described in phenomenon such as medically unexplained symptoms or somatisation $[5,7,9]$. Somatisation symptoms, when not adequately explained by organic findings, have been conceptualised as either I) somatic manifestation of psychological distress, II) or as somatic distress and the experience of medically unexplained symptoms without a strong assumption about causality, or III) as somatic syndromes characterised by specific clusters of somatic symptoms $[44,45]$. The present study cannot differentiate between these concepts, but gives support to the argument that we should avoid simple psychological explanations of these physical complaints [8]. Previous findings have shown a similar association between a five-item questionnaire pertaining to unexplained somatic symptoms in the general population and genes relevant for the neuroendocrine system [46]. Taken together, genetically mediated variance of these complaints suggests that physiological processes influenced by genotype may be explanatory in some individuals' symptom phenotype.

Duration of pain prior to baseline was an independent predictor for SHC in the present study. The female *G carriers had on average 23 weeks longer duration than male ${ }^{*} \mathrm{G}$ carriers. It is possible that duration of pain influenced the progress in SHC and pain scores - and that with longer durations also men would report increasing subjective health complaints. It has been shown in a similar cohort with lumbar radicular pain patients that those who report their pain as unchanged or worse, also report subjective health complaints as significantly elevated [2]. It is also possible that female ${ }^{*} \mathrm{G}$ carriers seek medical help at a later stage. However, female AA carriers had over 10 weeks longer duration than male AA carriers, without differing SHC scores. Moreover, male *G carriers had a shorter pain duration before inclusion 
and similar pain intensity, but still reported on average a faster recovery of their pain.

Previous studies have reported that individuals with one or more G-alleles have a reduced analgesic response to opioids. Thus, our lack of data on medication may be a potential confounder $[15,47]$. Moreover the inherent uncertainty in interpretation of genetic association studies and the low numbers of "G carriers emphasises the need for replication of our findings. Importantly, the frequency of G-variant carriers in the general population is low, 10.4\% among Caucasians has been reported [12]. The present finding can therefore only explain some of the variance of subjective health complaints in total.

\section{Conclusion}

The present data indicate that SHC in patients with radicular pain and disc herniation may be influenced by a polymorphism in the OPRM1 gene in a sex-specific manner. We conclude that SHC may be a trait that in itself is linked to the OPRM1 genotype.

\section{Additional file}

\section{Additional file 1: English version of the Subjective Health} Complaints Inventory.

\section{Abbreviations}

SNP: Single nucleotide polymorphism; OPRM1: $\mu$-opioid receptor 1; SHC: Subjective health complaints.

\section{Competing interests}

The authors declare that they have no competing interests. No support was received from commercial sources.

\section{Authors' contributions}

EH, EIS, CR and JG participated in the research design. EIS, CR, JG carried out the data collection. EH, LG, AJH and JG carried out the data analysis and drafting. All authors read and approved the final manuscript.

\section{Acknowledgements}

We thank Ada Ingvaldsen for technical assistance. Manuscript preparation was supported by a grant from Østfold Hospital Trust, Norway. South-Eastern Norway Regional Health Authority funds EH, EIS, LG, AJH and CR. The Research Council of Norway funds JG. The funders had no role in study design, data collection and analysis, decision to publish, or preparation of the manuscript.

\section{Author details \\ ${ }^{1}$ National Institute of Occupational Health, Oslo, Norway. ${ }^{2}$ Department of Physiotherapy, Østfold Hospital Trust, Fredrikstad, Norway. ${ }^{3}$ Department of Physical Medicine and Rehabilitation, Oslo University Hospital, Ullevål, Norway. ${ }^{4}$ Department of Rheumatology, Østfold Hospital Trust, Fredrikstad, Norway. ${ }^{5}$ Department of Biosciences, University of Oslo, Oslo, Norway.}

Received: 13 November 2013 Accepted: 9 May 2014

Published: 18 May 2014

\section{References}

1. Bacon NM, Bacon SF, Atkinson JH, Slater MA, Patterson TL, Grant I, Garfin SR: Somatization symptoms in chronic low back pain patients. Psychosom Med 1994, 56:118-127.

2. Grøvle L, Haugen AJ, Ihlebaek CM, Keller A, Natvig B, Brox JI, Grotle M: Comorbid subjective health complaints in patients with sciatica: $\mathrm{A}$ prospective study including comparison with the general population. J Psychosom Res 2011, 70:548-556.

3. Hestbaek L, Leboeuf-Yde C, Kyvik KO, Vach W, Russell MB, Skadhauge L, Svendsen A, Manniche C: Comorbidity with low back pain: a cross-sectional population-based survey of 12- to 22-year-olds. Spine 2004, 29:1483-1491. Discussion 1492

4. Hagen EM, Svensen E, Eriksen HR, Ihlebaek CM, Ursin H: Comorbid subjective health complaints in low back pain. Spine 2006, 31:1491-1495.

5. Deary IJ: A taxonomy of medically unexplained symptoms. J Psychosom Res 1999, 47:51-59.

6. Creed F, Guthrie E, Fink P, Henningsen P, Rief W, Sharpe M, White P: Is there a better term than "Medically unexplained symptoms?". J Psychosom Res 2010, 68:5-8.

7. Sharpe M, Carson A: "Unexplained" somatic symptoms, functional syndromes, and somatization: do we need a paradigm shift? Ann Intern Med 2001, 134:926-930.

8. Crombez G, Beirens K, van Damme S, Eccleston C, Fontaine J: The unbearable lightness of somatisation: a systematic review of the concept of somatisation in empirical studies of pain. Pain 2008, 145:31-35.

9. Eriksen HR, Ihlebaek C, Ursin H: A scoring system for subjective health complaints (SHC). Scand J Public Health 1999, 27:63-72.

10. Haugen AJ, Brox Jl, Grøvle L, Keller A, Natvig B, Soldal DM, Grotle M: Prognostic factors for non-success in patients with sciatica and disc herniation. BMC Musculoskelet Disord 2012, 13:183.

11. Campa D, Gioia A, Tomei A, Poli P, Barale R: Association of ABCB1/MDR1 and OPRM1 gene polymorphisms with morphine pain relief. Clin Pharmacol Ther 2008, 83:559-566.

12. Klepstad $\mathrm{P}$, Rakvåg TT, Kaasa $\mathrm{S}$, Holthe $\mathrm{M}$, Dale $\mathrm{O}$, Borchgrevink $\mathrm{PC}$, Baar $\mathrm{C}$, Vikan T, Krokan HE, Skorpen F: The $118 \mathrm{~A}>\mathrm{G}$ polymorphism in the human mu-opioid receptor gene may increase morphine requirements in patients with pain caused by malignant disease. Acta Anaesthesio/ Scand 2004, 48:1232-1239.

13. Oertel BG, Schmidt R, Schneider A, Geisslinger G, Lötsch J: The mu-opioid receptor gene polymorphism $118 \mathrm{~A}>\mathrm{G}$ depletes alfentanil-induced analgesia and protects against respiratory depression in homozygous carriers. Pharmacogenet Genomics 2006, 16:625-636.

14. Klepstad P, Fladvad T, Skorpen F, Bjordal K, Caraceni A, Dale O, Davies A, Kloke M, Lundström S, Maltoni M, Radbruch L, Sabatowski R, Sigurdardottir V, Strasser F, Fayers PM, Kaasa S, European Palliative Care Research Collaborative (EPCRC), European Association for Palliative Care Research Network: Influence from genetic variability on opioid use for cancer pain: a European genetic association study of 2294 cancer pain patients. Pain 2011, 152:1139-1145.

15. Reyes-Gibby CC, Shete S, Rakvåg T, Bhat SV, Skorpen F, Bruera E, Kaasa S, Klepstad P: Exploring joint effects of genes and the clinical efficacy of morphine for cancer pain: OPRM1 and COMT gene. Pain 2007, 130:25-30.

16. Fillingim RB, Kaplan L, Staud R, Ness TJ, Glover TL, Campbell CM, Mogil JS, Wallace MR: The A118G single nucleotide polymorphism of the mu-opioid receptor gene (OPRM1) is associated with pressure pain sensitivity in humans. J Pain 2005, 6:159-167.

17. Lötsch J, Stuck B, Hummel T: The human mu-opioid receptor gene polymorphism 118A $>\mathrm{G}$ decreases cortical activation in response to specific nociceptive stimulation. Behav Neurosci 2006, 120:1218-1224.

18. Sia AT, Lim Y, Lim ECP, Goh RWC, Law H-Y, Landau R, Teo Y-Y, Tan E-C: A118G single nucleotide polymorphism of human mu-opioid receptor gene influences pain perception and patient-controlled intravenous morphine consumption after intrathecal morphine for postcesarean analgesia. Anesthesiology 2008, 109:520-526.

19. Tan E-C, Lim ECP, Teo Y-Y, Lim Y, Law H-Y, Sia AT: Ethnicity and OPRM variant independently predict pain perception and patient-controlled analgesia usage for post-operative pain. Mol Pain 2009, 5:32.

20. Olsen MB, Jacobsen LM, Schistad El, Pedersen LM, Rygh LJ, Røe C, Gjerstad J: Pain intensity the first year after lumbar disc herniation is associated with the $\mathrm{A} 118 \mathrm{G}$ polymorphism in the opioid receptor mu 1 gene: evidence of a sex and genotype interaction. J Neurosci 2012, 32:9831-9834.

21. Matsunaga M, Isowa T, Murakami H, Kasugai K, Yoneda M, Kaneko H, Ohira H: Association of polymorphism in the human mu-opioid receptor OPRM1 gene with proinflammatory cytokine levels and health perception. Brain Behav Immun 2009, 23:931-935.

22. Stefano $G B$, Kream R: Endogenous opiates, opioids, and immune function: evolutionary brokerage of defensive behaviors. Semin Cancer Biol 2008, 18:190-198. 
23. Drolet G, Dumont EC, Gosselin I, Kinkead R, Laforest S, Trottier JF: Role of endogenous opioid system in the regulation of the stress response. Prog Neuropsychopharmacol Biol Psychiatry 2001, 25:729-741.

24. Wand GS, McCaul M, Yang X, Reynolds J, Gotjen D, Lee S, Ali A: The mu-opioid receptor gene polymorphism (A118G) alters HPA axis activation induced by opioid receptor blockade. Neuropsychopharmacology 2002, 26:106-114.

25. Mague SD, Blendy JA: OPRM1 SNP (A118G): involvement in disease development, treatment response, and animal models. Drug Alcohol Depend 2010, 108:172-182

26. Troisi A, Frazzetto G, Carola V, Di Lorenzo G, Coviello M, D'Amato FR, Moles A, Siracusano A, Gross C: Social hedonic capacity is associated with the A118G polymorphism of the mu-opioid receptor gene (OPRM1) in adult healthy volunteers and psychiatric patients. Soc Neurosci 2011, 6:88-97.

27. Way BM, Taylor SE, Eisenberger NI: Variation in the mu-opioid receptor gene (OPRM1) is associated with dispositional and neural sensitivity to social rejection. Proc Natl Acad Sci U S A 2009, 106:15079-15084.

28. Van Ree JM, Niesink RJ, Van Wolfswinkel L, Ramsey NF, Kornet MM, Van Furth WR, Vanderschuren LJ, Gerrits MA, Van den Berg CL: Endogenous opioids and reward. Eur J Pharmacol 2000, 405:89-101.

29. Lee MR, Gallen CL, Zhang X, Hodgkinson CA, Goldman D, Stein EA, Barr CS: Functional polymorphism of the mu-opioid receptor gene (OPRM1) influences reinforcement learning in humans. PLoS One 2011, 6:e24203.

30. Ihlebæk C, Eriksen $H$, Ursin $H$ : Prevalence of subjective health complaints (SHC) in Norway. Scand J Public Health 2002, 30:20-29.

31. Vandvik PO, Wilhelmsen I, Ihlebæk C, Farup PG: Comorbidity of irritable bowel syndrome in general practice: a striking feature with clinical implications. Aliment Pharmacol Ther 2004, 20:1195-1203.

32. Hurvich CM, Tsai C-L: A corrected Akaike information criterion for vector autoregressive model selection. J Time Anal 1993, 14:271-279.

33. Zubieta JK, Dannals RF, Frost JJ: Gender and age influences on human brain mu-opioid receptor binding measured by PET. Am J Psychiatry 1999, 156:842-848.

34. Ray R, Ruparel K, Newberg A, Wileyto EP, Loughead JW, Divgi C, Blendy JA, Logan J, Zubieta JK, Lerman C: Human Mu Opioid Receptor (OPRM1 A118G) polymorphism is associated with brain mu-opioid receptor binding potential in smokers. Proc Natl Acad Sci U S A 2011, 108:9268-9273.

35. Chong RY, Oswald L, Yang X, Uhart M, Lin P-I, Wand GS: The mu-opioid receptor polymorphism $\mathrm{A} 118 \mathrm{G}$ predicts cortisol responses to naloxone and stress. Neuropsychopharmacology 2006, 31:204-211.

36. Schwandt ML, Lindell SG, Higley JD, Suomi SJ, Heilig M, Barr CS: OPRM1 gene variation influences hypothalamic-pituitary-adrenal axis function in response to a variety of stressors in rhesus macaques.

Psychoneuroendocrinology 2011, 36:1303-1311.

37. Bart G, LaForge KS, Borg L, Lilly C, Ho A, Kreek MJ: Altered levels of basal cortisol in healthy subjects with a 118G allele in exon 1 of the $\mathrm{Mu}$ opioid receptor gene. Neuropsychopharmacology 2006, 31:2313-2317.

38. Milner TA, Burstein SR, Marrone GF, Khalid S, Gonzalez AD, Williams TJ, Schierberl KC, Torres-Reveron A, Gonzales KL, McEwen BS, Waters EM: Stress differentially alters mu opioid receptor density and trafficking in parvalbumin-containing interneurons in the female and male rat hippocampus. Synapse 2013, 67:757-772.

39. Huang $P$, Chen C, Mague SD, Blendy JA, Liu Chen LY: A common single nucleotide polymorphism $\mathrm{A} 118 \mathrm{G}$ of the $\mu$ opioid receptor alters its N-glycosylation and protein stability. Biochem J 2012, 441:379-386.

40. Ding N, Nie H, Sun X, Sun W, Qu Y, Liu X, Yao Y, Liang X, Chen CC, Li Y: Human serum $\mathrm{N}$-glycan profiles are age and sex dependent. Age Ageing 2011, 40:568-575.

41. Knezević A, Polasek O, Gornik O, Rudan I, Campbell H, Hayward C, Wright A, Kolcic I, O'Donoghue N, Bones J, Rudd PM, Lauc G: Variability, heritability and environmental determinants of human plasma N-glycome. J Proteome Res 2009, 8:694-701.

42. Stanta JL, Saldova R, Struwe WB, Byrne JC, Leweke FM, Rothermund M, Rahmoune H, Levin Y, Guest PC, Bahn S, Rudd PM: Identification of $\mathrm{N}$-glycosylation changes in the CSF and serum in patients with schizophrenia. J Proteome Res 2010, 9:4476-4489.

43. Wang YJ, Huang P, Ung A, Blendy JA, Liu-Chen LY: Reduced expression of the $\mu$ opioid receptor in some, but not all, brain regions in mice with OPRM1 A112G. Neuroscience 2012, 205:178-184.

44. de Gucht V, Maes S: Explaining medically unexplained symptoms: toward a multidimensional, theory-based approach to somatization. J Psychosom Res 2006, 60:349-352.
45. de Gucht V, Fischler B: Somatization: a critical review of conceptual and methodological issues. Psychosomatics 2002, 43:1-9.

46. Holliday K, Macfarlane G, Nicholl B, Creed F, Thomson W, McBeth J: Genetic variation in neuroendocrine genes associates with somatic symptoms in the general population: results from the EPIFUND study. J Psychosom Res 2010, 68:469-474.

47. Fukuda K, Hayashida M, Ide S, Saita N, Kokita Y, Kasai S, Nishizawa D, Ogai Y, Hasegawa J, Nagashima M, Tagami M, Komatsu H, Sora I, Koga H, Kaneko Y, Ikeda K: Association between OPRM1 gene polymorphisms and fentanyl sensitivity in patients undergoing painful cosmetic surgery. Pain 2009, 147:194-201.

doi:10.1186/1471-2474-15-161

Cite this article as: Hasvik et al:: Subjective health complaints in patients with lumbar radicular pain and disc herniation are associated with a sex - OPRM1 A118G polymorphism interaction: a prospective 1-year observational study. BMC Musculoskeletal Disorders 2014 15:161.

\section{Submit your next manuscript to BioMed Central and take full advantage of:}

- Convenient online submission

- Thorough peer review

- No space constraints or color figure charges

- Immediate publication on acceptance

- Inclusion in PubMed, CAS, Scopus and Google Scholar

- Research which is freely available for redistribution

Submit your manuscript at www.biomedcentral.com/submit
C) Biomed Central 